Розділ І. Ціннісні орієнтири духовно-інтелектуального виховання, розвиток духовно-інтелектуальних якостей особистості в умовах співпраці й інклюзії

\title{
ДУХОВНО-ІНТЕЛЕКТУАЛЬНЕ ВИХОВАННЯ МАЙБУТНІХ ЛІКАРІВ У ПРОЦЕСІ ВИВЧЕННЯ ПСИХОЛОГО-ПЕДАГОГІЧНИХ ДИСЦИПЛІН
}

\section{Кохан Д. М.}

викладачка кафедри української мови, основ психології та педагогіки, Харківський національний медичний університет, м. Харків, Україна

У статті проаналізовано програми начальних дисциплін «Основи педагогіки» та «Корекиіійна педагогіка», які викладають для здобувачів ХНМУ. На основі аналізу зазначених курсів розкрито способи духовно-інтелектуальне виховання майбутнього лікаря під час практичних занять, який би поєднував найкращі риси справжнього професіонала.

Ключові слова: педагогіка, емпатія, духовно-інтелектуальне виховання, майбутній лікар.

The article analyzes the programs of primary disciplines «Fundamentals of Pedagogy» and "Correctional Pedagogy», which are taught to students of KhNMU. Based on the analysis of these courses, the spiritual and intellectual education of the future doctor during practical classes, which would combine the best features of a true professional, is revealed.

Key words: pedagogy, empathy, spiritual and intellectual education, future doctor

Реалії життя показують, що молоде покоління деградує духовно, а їхній інтерес сконцентрований на матеріальні блага, реальне спілкування змінює віртуальне, а відтак й ставлення до інших є жорстоким, грубим. Слід звернути увагу на те, що майбутні лікарі — це еліта нашої держави, саме у їхніх руках найважливіше, що має людина - це піi здоров'я та життя. У зв'язку з пандемією COVID-19 все населення планети стало «паралізованим»: літаки перестали літати, майже всі магазини зачинилися, перетинати кордони заборонено, заклади освіти перейшли працювали в дистанційний режим. На плечі викладачів покладені питання пов’язані не тільки з підготовкою майбутніх професіоналів, але й їхнім вихованням, які гідно будуть представляти нашу країну на світовій арені.

На жаль, самі здобувачі не зацікавленні у вивченні таких дисциплін, як: «Основи педагогіки», «Основи психології та педагогіки», «Корекційна педагогіка» тощо, бо не вбачають сенсу в здобутті знань 3 непрофільних предметів. 
Мета дослідження полягає в розкритті духовно-інтелектуального виховання майбутніх лікарів у процесі вивчення психолого-педагогічних дисциплін.

Виховні аспекти діяльності медичних закладів розкривалися у працях таких науковців: О.Андрійчук (виховання гуманності студентів медичних коледжів), А.Асламова (виховання морально-етичної культури майбутнього лікаря), О. Гепенко (міжкультурне виховання майбутніх лікарів) Х.Мазепа (організаційно-педагогічні умови виховної роботи в медичному коледжі) та інші. Однак слід зазначити, що духовно-інтелектуальне виховання майбутніх лікарів у процесі вивчення психолого-педагогічних дисциплін досі мало досліджений напрям.

Нами було проаналізовано навчальні програми дисциплін «Основи педагогіки», «Корекційна педагогіка», які викладають здобувачам у Харківському національному медичному університеті, що дало змогу звернути увагу на виховний аспект під час вивчення кожної 3 них.

3 метою з'ясування мотивів вибору дисципліни «Основи педагогіки» (саме вона була вибіркова) на першому практичному занятті майбутні лікарі спробували подискутувати на тему «Чи потрібно вивчати педагогіку в медичному ВНЗ? Чому?». Ця тема підняла неабияке зацікавлення з боку студентів, однак їхні погляди спочатку розділися на «за» та «проти». Однак, за допомогою технології «Два, чотири, всі разом» було отримано висновок: вивчення педагогіки необхідне, перш за все, тим здобувачам, які вбачають своє майбутнє у педагогічній діяльності, однак і тим, хто пов'язує своє життя лише 3 професією лікаря, тому що педагогічні знання стануть у нагоді у ході роботи з дітьми різного віку та їхніми батьками, дорослими пацієнтами та їхніми родичами, у процесі спілкування з колегами тощо, під час проведення семінарів для інтернів, профілактичних лекцій для населення тощо.

На практичному занятті $з$ теми «Контроль, перевірка та оцінка навчальних досягнень» здобувачі за розв’язали проблемне питання «Як оцінити діяльність лікаря?». Також на цьому занятті була проведена дискусія «Чи має право на помилку лікар?»

Під час заняття на тему «Сутність, зміст і структура виховання. Принципи та методи виховання» за допомогою технології «Бджолині групи» студенти розкрили питання щодо процесу виховання в про- 
Розділ І. Ціннісні орієнтири духовно-інтелектуального виховання, розвиток духовно-інтелектуальних якостей особистості в умовах співпраці й інклюзії

фесійній діяльності лікаря та його значення. Майбутні лікарі під час виконання завдання проявляли повагу, толерантність один до одного, враховували думки інших та відстоювали свою позицію.

У процесі вивчення курсу «Корекційна педагогіка» здобувачам було запропоновано виконання низки вправ, зокрема, вправи «Ми творимо». Це дозволило студентам усвідомити, що всі здобувачі рівні, мають однакові можливості для розвитку особистості, але кожен має свою унікальність. 3 метою відчуття почуттів людини з вадами зору була проведена вправа «Поводир», де студенту-поводиру потрібно було розказати шлях, який необхідно було подолати, а тому, хто його долає треба було зробити це із заплющеними очима. Вправа «Переживи почуття іншого» також була спрямована на розвиток емпатійних вмінь до іншої людини. Студенти описували людину, до якої виникають почуття емпатії й намагалися розповісти історію від іiі імені. Хотілося б зазначити, що сама ця вправа найбільше проникла в душу кожного, майже всі студенти не могли стримати сліз, що свідчило про їхні душевні переживання за іншу людину.

Слід також зазначити, що майже кожне заняття вищезазначених дисциплін супроводжувалося розв'язанням життєвих та змодельованих ситуацій, а також їхнім аналізом, обговоренням теоретичних питань, підведенням підсумків. Зокрема під час перших занять студентам було запропоновано виконати вправу «Будьмо знайомі», де здобувачі мали себе презентувати у нетрадиційній формі. Наприклад, була студентка, яка уособила себе з мишеням, яке збирає по зернятку необхідні знання до себе у нірку; хтось вважав себе левом, якому під силу всі перепони; дехто назвався котом, який би тільки їв, спав, насолоджувався життям та час від часу ходив на полювання. Наприкінці вивчення зазначених дисциплін серед здобувачів було проведено анкетування «Образ ідеального лікаря», який уособлював би в собі найкращі риси професіонала.

Отже, у процесі вивчення психолого-педагогічних дисциплін важливо звертати увагу не тільки на підготовку майбутнього фахівця, але й на виховання особистості здобувача, адже ці процеси невід'ємні один від одного, й характеризують його як справжнього професіонала, який здатен проявляти моральні якості у хвилини, коли йому довіряють життя людини, а ці курси мають великий потенціал для духовно-інтелектуального розвитку майбутнього лікаря. 